\title{
Digital image analysis of skin neoplasms evaluated by lectin histochemistry: potential marker to biochemical alterations and tumour differential diagnosis
}

\author{
Análise digital de imagens de neoplasias da pele avaliadas pela histoquímica com lectinas: marcador potencial \\ para alterações bioquímicas e diagnóstico diferencial de tumores
}

Mario R. Melo-Júnior'; Jorge Luiz S. Araújo-Filho²; Vasco José Ramos M. Patu; Marcos Cezar F. de Paula Machado²; Eduardo I.C. Beltrão ${ }^{4}$; Luiz B. Carvalho Jr. ${ }^{5}$

key words

Basal cell carcinoma

Lectins

Image analysis

Skin neoplasms

\section{abstract}

The present study aims to evaluate, through lectin histochemistry, the alterations in the expression of cell surface carbohydrate between benign and malignant lesions of skin using computer image analysis. Skin fragments were obtained through biopsies and diagnosed as basal cell carcinoma (BCC), epidermoid carcinoma (EpC), trichoepithelioma (TE), keratoacanthoma (KA), seborrheic keratosis (SK) and actinic keratosis (AK). Lectins Con A, WGA, PNA, UEA-I and LTA were used in histochemistry study. Image analysis was carried out in a workstation using OPTIMAS ${ }^{\mathrm{TM}}$ software system. PNA strong binding pattern to studied tumours evidenced the high expression of D-galactose residues in the epidermal neoplasms when compared to other sugars recognized by the other lectins. Among benign neoplasms, KA presented a high expression of glucose/mannose, $\alpha$-fucose and D-galactose residues evidenced by the intense staining of Con A (94.7\%), LTA (84.2\%) and PNA (89.4\%), respectively. Malignant tumours showed distinct binding patterns. EpC presented significant binding only by PNA lectin. BCC was differentially stained in comparison to the staining pattern observed in benign lesions such as TE. Qualitative (lectin histochemistry) and quantitative (digital image analysis) data obtained in this study evidenced those lectins are potential markers to biochemical alterations in skin neoplasms.

O presente estudo objetivou avaliar, através da histoquímica com lectinas, as alterações na expressão dos carboidratos da superfície celular entre lesões benignas e malignas da pele usando análise de imagens computadorizadas. Fragmentos de pele foram obtidos através de biópsias e diagnosticados como carcinoma basocelular (CBC), carcinoma epidermóide (EpC), tricoepitelioma (TE), cerato acantoma (KA), ceratose seborreica (CS) e ceratose actínica (CA). As lectinas Con A, WGA, PNA, UEA-I e LTA foram usadas no estudo histoquímico. A análise de imagens foi realizada numa estação de análise usando o sistema OPTIMASTM de análises. A PNA tem sido largamente utilizada no estudo de tumores, evidenciando a expressão de D-galactose nas neoplasias epidérmicas; esse açúcar apresenta alta expressão quando comparado com os outros reconhecidos pelas demais lectinas. Entre as neoplasias benignas, $K A$ apresentou alta expressão glucose/manose; resíduos de $\alpha$-fucose e $D$-galactose apresentaram intensa marcação com ConA $(94,7 \%)$ LTA $(84,2 \%)$ e PNA (89,4\%), respectivamente. Os tumores malignos mostraram marcações distintas: EpC apresentou marcação significativa somente com a lectina PNA; CBC apresentou diferente padrão de marcação quando comparado ao observado nas lesões benignas assim como no TE. Os resultados qualitativos (análise de imagens) e quantitativos (histoquímica com lectinas) desse estudo evidenciaram que as lectinas têm grande potencial como marcadores de alterações bioquímicas nas neoplasias da pele.

1. Professor-titular de Patologia da Associação Caruaruense de Ensino Superior (ASCES).

2. Mestrando em Patologia pelo Centro de Ciências da Saúde (CCS) da UFPE.

3. Mestrando em Ciências Biológicas pelo Centro de Ciências Biológicas (CCB) da UFPE.

4. Professor-adjunto do Departamento de Bioquímica do CCB/UFPE.

5. Professor-titular do Departamento de Bioquímica do CCB/UFPE.

Trabalho realizado no Laboratório de Imunopatologia Keizo Asami (LIKA) da Universidade Federal de Pernambuco (UFPE). 


\section{Introduction}

The difficulty in diagnosing many skin neoplasias is related to a variety of factors such as a huge spectrum of tumours and their variants and the lower differentiation and complicated nomenclature(43). Besides that, many studies are inconclusive to affirm whether the cellular origin of some malignant lesions is derived from benign tumour differentiation and pre-neoplasic tumours or from normal cell(42).

In routine histology, there is not a precise staining pattern to differentiate all skin tumours. Epidermis neoplasic lesions such as squamous cell carcinoma and keratoacanthoma are many times difficult to be differentiated from each other using routine histology analysis ${ }^{(7)}$. Trichoepithelioma and basocellular carcinoma; or Bowen disease, actinic keratosis and seborrheic keratosis histology differentiation can be also difficult in small tissue samples ${ }^{(16,32)}$.

Immunohistochemistry techniques ${ }^{(33)}$ and lectin staining ${ }^{(3,27)}$ have been tested as supporting tools for differential diagnosis for skin lesions.

Investigation of lectin/carbohydrate interactions helps in the understanding of histogenetic origin and tumour behaviour during its differentiation ${ }^{(14)}$ and confirms the hypothesis that biochemistry changes in the cell are events that can signalize cell morphodifferentiations ${ }^{(36)}$. Glycosylation and glycoconjugate expression are usually altered in tumour cells in comparison to their normal counterpart ${ }^{(4,24)}$.

The results of the very few histochemical studies that have been performed so far on the lectin-binding profile of normal human epidermis are mostly controversial; thus, the carbohydrate residue composition of the cell surface in the latter still remains in dispute, and the possible alterations in the epidermal lectin-binding profile are unknown ${ }^{(11)}$.

In comparison with normal human skin, epidermal lectinbinding pattern in the tumour cells showed considerable qualitative and quantitative variations ${ }^{(13)}$.

Many methods of analysis have been used to translate in objective and numerically representative standards the transformations occurred in tumour cells ${ }^{(10)}$. Such methods include colorimetric analysis of neoplasic cell culture(1), automatic cytometry ${ }^{(28)}$, nuclear morphometric variation analysis ${ }^{(35)}$ and image analysis of tumour lectin staining ${ }^{(22,25)}$.

Digital image analysis has given more accurate quantitative and qualitative data of histomorphologic aspects of neoplasms ${ }^{(8,23)}$. From this perspective the present study aims to evaluate the differences of cell surface carbohydrate expression between benign and malignant lesions of the skin using lectin staining and digital image analysis.

\section{Material and methods}

\section{Case selection}

Skin fragments were obtained through biopsies and diagnosed as basal cell carcinoma (BCC, $n=35$ ), epidermoid carcinoma (EpC, $n=18$ ), trichoepithelioma (TE, $n=12$ ), keratoacanthoma (KA, $n=19$ ), seborrheic keratosis (SK, $n$ $=10$ ) and actinic keratosis (AK, $n=18)$. Normal human epidermis (NE, $n=25$ ) samples were obtained from the same anatomical site on the opposite side of the tumours. Patients (male and female), whose ages varied from 45 to 80 years old, agreed to participate in this study and signed a consent declaration. The delineation of the study was a retrospective analysis based on paraffin blocks from archived cases (Laboratório de Imunopatologia Keizo Asami [LIKA] of Universidade Federal de Pernambuco [UFPE]).

\section{Tissue preparation}

Biopsies were fixed in $10 \%$ buffered formalin, submitted to histological routine, and paraffin embedded. Slices $(4 \mu \mathrm{m})$ were adhered in slides treated with 3-aminepropyltriethoxy-silane (APES [Sigma, USA]).

\section{Lectin histochemistry}

Concanavalin $A(\operatorname{Con} A)$, wheat germ agglutinin (WGA), peanut agglutinin (PNA), Ulex europaeus agglutinin (UEA-I) and Tetragonolobus purpurea agglutinin (LTA) conjugated to peroxidase (Sigma, USA) were used. Tissues were deparaffinized in xylene and hydrated through graded alcohol. Slices were treated with $0.1 \%(\mathrm{w} / \mathrm{v})$ trypsin solution at $37^{\circ} \mathrm{C}$ for two minutes, followed by $0.3 \%(\mathrm{v} / \mathrm{v})$ methanolic hydrogen peroxide, for 20 minutes at room temperature and incubated with conjugated lectins (Con A, $100 \mu \mathrm{g} / \mathrm{mL}$; WGA, PNA, UEA-I and LTA, $80 \mu \mathrm{g} / \mathrm{mL}$ ) for two hours at $4^{\circ} \mathrm{C}$. Slides were washed (twice, 5 minutes each time) with $10 \mathrm{mM}$ phosphate buffer, containing $0.15 \mathrm{MNaCl}$ (PBS), pH 7.2, after each step. Peroxidase was visualized by incubation in PBS containing 3,3-diaminobenzidine (DAB) and hydrogen peroxide $\left(\mathrm{H}_{2} \mathrm{O}_{2}\right)$ for five to eight minutes. Tissue sections were counterstained with Harry's haematoxylin and evaluated through optical microscopy. Inhibition assays of lectin-carbohydrate recognition were 
performed using the corresponding lectin specific sugar: methyl- $\alpha$-D-mannoside for Con A; N-acetyl-glucosamine for WGA; $\alpha$-L-fucose for UEA-I and LTA; and D-galactose for PNA, at final concentration of $300 \mathrm{mM}$.

\section{Digital image analysis}

Images of slices of the stained cells (magnification 100x) were obtained using a digital video camera (Sony, Japan) connected to a microscope and processed using OPTIMAS ${ }^{\mathrm{TM}}$, version 6.1 (Optimas Corporation, USA). Fields were chosen randomly from various section levels to ensure objectivity of sampling. The files were then opened in Adobe Photoshop (Adobe Inc., Mountain View, CA) and further processed to assess stained cells. To accomplish this, acquired color images were first split into red, green, and blue channels (Optimas Commander: Split channels).

The images were binarized to black and white and a common threshold level was chosen for representing correct stained cells and minimizing background noise levels (Optimas Commander: Adjust Threshold). To investigate changes in lectin binding patterns revealed by the DABperoxidase reaction we employed the following method: red channel images were initially blurred with a Gaussian filter (one pixel for all sample images) to reduce electronic and background noise (Optimas Commander: Filter: Blur: Gaussian blur); eight-bit grayscale levels were expanded linearly so that the whitest point fell at a grayscale value of 255 and the blackest point at 0 ; the images were then so that all points above the chosen grayscale value were included for measurement and those below were excluded.

However, a common threshold level was chosen for all analyzed images to prevent intra-assay variations. We then inverted the images, which changed all white pixels to black ones and vice versa (Optimas Commander: Adjust: Invert), and employed the image processing for further analysis. Staining control (tissues treated with sugar-inhibited lectins and normal skin samples) was obtained to minimize distortions in values due to the presence of non-marked cells, thus a correction factor (CF) was applied according to the equation $\mathrm{CF}=s / S$, in which $s$ means relative area of the surface and $S$, the total measured area ${ }^{(24)}$.

Analyses were developed in three areas, randomly chosen, of the stained tumour tissue where the mean area $\left(\mu \mathrm{m}^{2}\right)$ and the number of cells per area (total area: 12234 $\mu \mathrm{m}^{2}$ ) were calculated. Dermal and hypodermal vessel areas were omitted. Obtained data were compared using MannWhitney $U$ test and Student's $t$ test $(p<0.05)$ through PRISMA 3.0 software (Texas, USA).

\section{Results}

Tissue samples presented a homogeneous characterization related to morphologic features related to sex and age (Table 1). Among benign neoplasias, KA presented a high expression of glucose/mannose, $\alpha$-fucose and D-galactose residues evidenced by the intense staining of Con $A$ (94.7\%), LTA (84.2\%) and PNA (89.4\%), respectively. AK exhibited positive staining to PNA and WGA, being negative or irregular $(<5 \%)$ for the other lectins staining. The lowest staining was observed for trichoepithelioma.

Lectins presented a varied staining pattern. Specific staining was observed to Con A, WGA and PNA while LTA and UEA-I presented non-specific staining. Epidermal cornea layer was stained by all used lectins. The strong binding pattern of studied tumours by PNA evidenced the high expression of D-galactose residues in the epidermal neoplasms when compared to other sugars recognized by the other lectins (Figure 1).

\section{Table 1 General aspects of the lesions from patients with skin tumours}

\begin{tabular}{lcccccc}
\hline Tumor* & \multicolumn{2}{c}{ Age (years) ${ }^{* *}$} & \multicolumn{2}{c}{ Tumor size $\left(\mathrm{cm}^{2}\right)^{* *}$} & \multicolumn{2}{c}{ Total biopsies } \\
& Male & Female & Male & Female & Male & Female \\
BCC & $55.2 \pm 4.8$ & $58.1 \pm 3.7$ & $1.06 \pm 0.21$ & $1.37 \pm 0.86$ & 12 & 10 \\
TE & $61.3 \pm 2.3$ & $47.5 \pm 2.1$ & $0.64 \pm 0.21$ & $1.83 \pm 1.13$ & 11 & 10 \\
SK & $57.1 \pm 7.8$ & $44.8 \pm 4.5$ & $0.86 \pm 0.21$ & $1.24 \pm 0.15$ & 10 & 10 \\
KA & $53.2 \pm 5.6$ & $52.7 \pm 2.2$ & $2.05 \pm 1.21$ & $1.63 \pm 0.96$ & 10 & 9 \\
AK & $54.8 \pm 3.5$ & $53.9 \pm 3.4$ & $2.31 \pm 2.01$ & $2.4 \pm 0.52$ & 12 & 10 \\
EpC & $55.6 \pm 5.8$ & $59 \pm 5.1$ & $0.97 \pm 0.33$ & $0.88 \pm 0.16$ & 12 & 10 \\
\hline
\end{tabular}

${ }^{*}$ According to Elder et al. 1997(9). The main anatomical sites were neck, arm and head; ${ }^{*}{ }^{*}$ statistic analysis (Tukey test; $p=0.73 ; r=1.25$ ). 


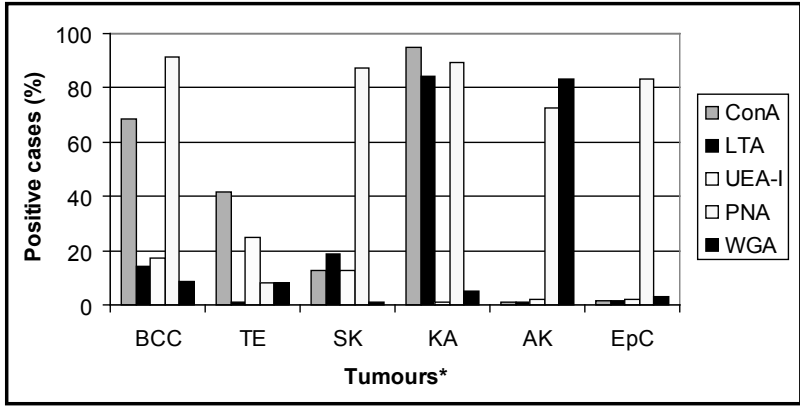

Figure 1 - Results of image analysis of stained cells area obtained to lectin histochemistry of skin's neoplasms. *Basal cell carcinoma (BCC, $n=35)$, epidermoid carcinoma (EpC, $n=18$ ), trichoepithelioma (TE, $n=12)$, keratoacanthoma (KA, $n=19)$, seborrheic keratosis (SK, $n=10)$ and actinic keratosis ( $A K, n=18$ ). Lectins: Con $A$ (concanavalin A), WGA (wheat germ agglutinin), PNA (peanut agglutinin), UEA-I (Ulex europaeus agglutinin) and LTA (Tetragonolobus purpurea agglutinin). Total area analyzed per slice: $12,234 \mu \mathrm{m}^{2}$.

Malignant tumours showed distinct binding patterns. EpC presented significant binding only to PNA lectin. Basocellular carcinoma was differentially stained in comparison to the staining pattern observed in benign lesions such as TE.

Statistically significant variations were not observed in the image analysis data of area and number of cells in the evaluated skin tumours (Table 2).

\section{Discussion}

Qualitative and quantitative changes in the glycoconjugates of cell membranes are normal during development and progression of many neoplasic processes ${ }^{(6,39,44)}$. In neoplasic cells the increase on the content and/or expression of surface carbohydrates have been documented using lectin histochemistry ${ }^{(14,40)}$. Lectins are sensible, stable and easy-touse tools to differentiate transformed and non-transformed cells $(4,9,24,37)$.
WGA and PNA stained similarly the cornea layer and collagen tissue of both benign and malignant tumours. Previous studies demonstrated the presence of glycoproteins in these tissues ${ }^{(14,15)}$.

Many lectins, such as Helix pomatia agglutinin (HPA) and PNA, recognize tumour cells of malignant melanomas ${ }^{(42)}$, indicating the association of surface carbohydrates with the metastatic potential of skin cancers ${ }^{(45)}$. The differentiated expression of sugars during transformation of melanocytes into keratocytes can be used as a distinct marker between benign and malignant skin lesions ${ }^{(27,29)}$.

In our study PNA presented a high binding profile to BCC, EpC, SK and KA. Other studies concluded that PNA presented intense binding pattern to $K A$ and squamous cell carcinoma ${ }^{(17,18)}$. In both cases, aberrant glycosylation may be associated to a differential cell surface expression of extra cellular matrix receptors in the transformed cell(5).

The differentiation between BCC and TE is sometimes difficult due to the histology of these lesions ${ }^{(26)}$. This distinction is clinically very important since BCC must be completely excised because of its aggressive behaviour to local recurrence while TE is a benign tumour, which can be treated with a superficial excision, not requiring another treatment or intervention ${ }^{(38)}$. Our results demonstrated that specially Con A and PNA can be used as markers for distinction between $B C C$ and TE indicating pathobiochemical specific alterations originated from these neoplasms.

Similar studies to evaluate the cell surface glycoconjugates using PNA, WGA, Con A, LTA and UEA lectins did not observe total accordance concerning lectin-binding ${ }^{(12,13)}$. On the other hand, this is probably due to the different fixatives and histological routine process employed in each research.

Table 2

Image analysis data of lectin histochemistry in the area and number of cells stained on skin

Tumour* tumours

\begin{tabular}{lcc} 
Tumour* & Parameter \\
BCC & Number of cells** & Cellular area $\left(\mu \mathrm{m}^{2}\right)$ \\
TE & $388.2 \pm 58.2$ & $4.92 \pm 1.16$ \\
SK & $403.7 \pm 80.6$ & $3.17 \pm 0.79$ \\
KA & $435.1 \pm 82.6$ & $3.06 \pm 0.76$ \\
AK & $410 \pm 65.6$ & $3.66 \pm 0.91$ \\
EpC & $390.2 \pm 54.6$ & $4 \pm 1.12$ \\
\hline
\end{tabular}

*Basal cell carcinoma (BCC, $n=35)$, epidermoid carcinoma (EpC, $n=18)$, trichoepithelioma $(T E, n=12)$, keratoacanthoma $(K A, n=19)$, seborrheic keratosis (SK, $n=10)$ and actinic keratosis $(A K, n=18)$; ${ }^{* *}$ average of cells that stained positively \pm standard deviation. 
Quantitative image analysis of the number and area of cells confirmed that the histological differentiation in tumours seem to be also related to changes in the expression of surface carbohydrates in cells ${ }^{(21,25,34)}$. Aberrant glycosylation of tumour cells, defined by the expression of tumour associated carbohydrate antigens (TACAs), is even more frequently found in tumours than activation of certain oncogenes, such as ras. Thus, the TACAs have been used as markers for prognosis of human tumours ${ }^{(5,30)}$.

Cell surface glycoconjugates have an important hole in cell/cell interaction, and changes in these glycoconjugates in cancer cells are apparently associated to the altered cell adhesion and development of tumour invasive features ${ }^{(31)}$. The final composition of cell glycoconjugates is determined by the combined activities of cell glycosyltransferase and glycosidases. The genetic regulation of these groups of enzymes is still poorly understood, but quantitative and qualitative differences in the glycosylation have been considered to reflect differences in gene expression ${ }^{(19)}$.

Our results get together to the findings of other authors who investigated similar and different diseases, which used Con A, PNA, WGA and UEA-I to characterize tumour parenchyma in $\mathrm{BCC}^{(20)}$, Paget disease by WGA and $\mathrm{PNA}^{(41)}$ and epithelioid hemangioendothelioma by UEA-I(2).

Despite the results, it can be concluded that, in general, the more anaplasic (undifferentiated) a cell becomes the more intense the staining of some lectins can be. This observation indicates that the distribution and expression of glyconjugates in the surface were altered ${ }^{(40)}$. The Con A, LTA and PNA lectins were useful and distinguished among benign and malignant epidermal neoplasms.

Qualitative (lectin histochemistry) and quantitative (image analysis) data obtained in this study evidence that lectins are potential markers and tools to biochemical alterations in skin neoplasms.

\section{Acknowledgments}

We thank Carmelita de Lima Bezerra Cavalcanti and Valdir Bandeira Silva, M.D. (Universidade Federal de Pernambuco, Brazil) for technical and scientific assistance, respectively. This work was supported by CNPq (CTPETRO no 463655/001).

\section{References}

I. ALLEY, M. C. et al. Morphometric and colorimetric analysis of human tumor-cell line growth and drug sensitivity in soft agar culture. Cancer Res, v. 5 I, n. 4, p. I247-56, 199 I.

2. ARNOLD, G.; KLEIN, P. J.; FISHER, R. Epithelioid hemangioendothelioma. Report of a case with immunolectinhistochemical and ultrastructural demonstration of its vascular mature. Virchows Arch (Pathol Anat), v. 408, p. 435-43, 1986.

3. BASARAB, T.; ORCHARD, G.; RUSSELL-JONES, R The use of immunostaining for bcl-2 and CD 34 and the lectin peanut agglutinin in differentiating between basal cell carcinomas and trichoepitheliomas. Am J Dermatopathol, v. 20, n. 5, p. 448-52, 1998.

4. BELTRÃO, E. I. C.; CARVALHO Jr., L. B. Parkia pendula lectin as histochemistry marker for meningothelial tumour. Eur J Histochem, v. 47, n. 2, p. I39-42, 2003

5. CHAMMAS, R. et al. Carbohydrate-binding proteins in cell-matrix interactions. Braz J Med Biol Res, v. 27, p. 21 69-79, 1994.

6. CHAN, F. L.; CHOI, H. L.; HO, S. M. Analysis of glycoconjugate patterns of normal and hormone-induced dysplastic noble rat prostates and an androgen-independent noble rat prostate tumor by lectin and protein blotting. Prostate, $\mathrm{v}$ 46, n. I, p. 21-32, 2001.

7. CRIBIER, B.; ASCH P. H.; GROSSHANS, E. Differentiating squamous cell carcinoma from keratoacanthoma using histopathological criteria. Is it possible ? A study of 296 cases. Dermatol, v. 199, n. 3, p. 208-12, 1999.

8. DEMIRKAYA, O. et al.Automated identification of stained cells in tissue sections using digital image analysis. Anal Quant Cytol Histol, v. 21, n. 2, p. 93-102, 1999.

9. ELDER, D. et al. Laboratory methods. In: ELDER, D. et al. Lever's Histopathology of the skin. 8. ed. New York: Lippincort-Raven, 1997. Cap. 4, p. 1073.

I0. FRANCIS, I. M. et al. Manual versus image analysis estimation of PCNA in breast carcinoma. Anal Quant Cytol Histol, v. 22, n. I, p. I I-6, 2000.

1 I. GEORGIOW, S. et al.Age-related alterations in the carbohydrate residue composition of the cell surface in the unexposed normal human epidermis. Gerontol, v. 5I, p. 155-60, 2005.

12. GHERI, G. et al. Changes in expression of the oligosaccharides in the human fetal skin. Ann Anat, v. 179, n. I, p. 49-56, 1997.

13. GHERI, G. et al. The oligosaccharidic component of the glycoconjugates in lichen planus, granuloma annulare, seborrheic keratosis and plamoplantar keratoderma: lectin histochemical study. Histol Histopathol, v. 14, n. 3, p. 697704, 1999.

14. HERLING, M. et al. Glycohistochemical monitoring of chemically induced sarcomas at different stages of tumorigenesis. In Vivo, v. I4, n. 4, p. 499-506, 2000.

I5. HOLT, P. J. A.; ANGLIN, J. H.; NORDQUIST, R. E. Localization of 
specific carbohydrate configurations in human skin using fluorescein-labelled lectins. Brit J Dermatol, v. 100, p. 23745, 1979.

16. ISHIDA, H. et al. Comparative histochemical study of Bowen's disease and actinic keratosis: perserved normal basal cells in Bowen's disease. Eur J Histochem, v. 45, n. 2, p. 177-90, 2001.

17. KANITAKIS, J. et al. Nucleolar organizer region enumeration in keratoacanthomas and squamous cell carcinomas of the skin. Cancer, v. 69, n. 12, p. 2937-4I, 1992.

18. KANNON, G.; PARK, K. Utility of peanut agglutinin (PNA) in the diagnosis of squamous cell carcinoma and keratoacanthoma. Am J Dermatopathol, v. 12, p. 31-6, 1990.

19. KROGERUS, L.; ANDERSON, L. C. Different lectin binding patterns in primary breast cancers and their metastases. Cancer, v.66, p. I 802-9, 1990

20. KRÜGER, K.; BLUME-PEYTAVI, U.; ORFANOS, C. E. Basal cell carcinoma possibly originates from the outer root sheat and/or the bulge region of the vellus hair follicle. Archiv Dermatol Res, v. 29I, n. 5, p. 253-9, 1999.

21. LALWANI,A. K. et al. Lectin binding characteristics of squamous cell carcinomas of the head and neck. Acta Otolaryngol, v. I 16, p. |25-31, 1996.

22. LATHAM, V. H.; OPPENNHEIMER, S. B. A simple image analysis method for evaluating cell binding to derivatized beads. Acta Histochem, v. I01, n. 3, p. 263-70, 1999.

23. LEE, J. S.; JUNG, J. J.; KIM, J. Quantification of angiogenesis by a computerized image analysis system in renal cell carcinoma. Anal Quant Cytol Histol, v. 22, n. 6, p. 469-74, 2000.

24. LITYNSKA, A. et al. Comparison of the lectin-binding pattern in different human melanoma cell lines. Melan Res, v. I I, n. 3, p. 205-12, 2001.

25. MELO-JÚNIOR, M. R. et al.Altered lectin-binding sites in normal colon and ulcerative colitis. J Bras Patol Med Lab, v. 40, n. 2 , p. I23-5, 2004.

26. MILLER, S. J. Biology of basal cell carcinoma (Part I). J Am Acad Dermatol, v. 24, p. I- 13, 1991.

27. MINWALLA, L. et al. Inhibition of melanosome transfer from melanocytes to keratinocytes by lectins and neoglycoproteins in vivo and in vitro model system. Pig Cell Res, v. 14, n. 3, p. |85-94, 200|.

28. MOMMERS, E. C. M. et al. Malignancy-associated changes in breast tissue detected by image cytometry. Anal Cell Pathol, v. 20, n. 4, p. 187-95, 2000.

29. MONASTIRLI, A. et al. Lectin-binding pattern of primary malignant melanomas and melanocytic nevi.J Cut Pathol, v. 27, n. 3, p. 103-7, 2000
30. MURAMATSU,T. Carbohydrate signals in metastasis and prognosis of human carcinomas. Glycobiol, v. 3, p. 29I-6, 1993.

31. OKUYAMA,T. et al. Interrelation between tumor-associated cell surface glycoprotein and host immune response in gastric carcinoma patients. Cancer, v. 82, n. 8, p. 1468-75, 1998.

32. PETTER, G.; HAUSTEIN, U. F. Rarely occurring and newly described histological variants of cutaneous squamous cell carcinoma. Classification based on histopathology, cytomorphology and biologic behavior. Hautarzt, v. 52, n. 4, p. 288, 2001.

33. PONIECKA, A. W.; ALEXIS, J. B. An immunohistochemical study of basal cell carcinoma and trichoepithelioma. Am J Dermatopathol, v. 21, n. 4, p. 332-6, 1999.

34. REANO, A. et al. Lectins as markers of human epidermal cell differentiation. Differentiation, v. 22, p. 205-10, 1985.

35. ROELS, S. L. M. F. et al. DNA ploidy and nuclear morphometric variables for the evaluation of melanocytic tumors in dogs and cats. Am J Vet Res, v. 61, n. 9, p. 1074-9, 2000.

36. SALZMAN, N. H. et al. Enteric defensin expression in necrotizing enterocolitis. Pedriatr Res, v. 44, p. 20-6, 1998.

37. SCHUMACHER, D. V. et al. Is the binding of the lectin Helix pomatia agglutinin (HPA) of prognostic revelance in tumours of the upper aerodigestive tract? Eur J Surg Oncol, v. 22, n. 6, p. 618-20, 1996.

38. SMOLLER, B. R. et al. bcl-2 expression reliably distinguishes trichoepitheliomas from basal cell carcinomas. Brit J Dermatol, v. |31, p. 28-31, 1994.

39. TAKAHASHI, T. et al. Alpha I,6 fucosyltransferase is highly and specifically expressed in human ovarian serous adenocarcinomas. Int J Cancer, v. 88, n. 6, p. 9|4-9, 2000.

40.TAKANO,Y. et al. Lymph node metastasis-related carbohydrate epitopes of gastric cancer with submucosal invasion. Surgery Today, v. 30, n. 12, p. 1073-82, 2000.

4I. TAMAKI, K. et al. Lectin-binding sites in Paget's disease. Brit J Dermatol, v. II3, p. 17-24, 1985.

42.THIES,A. et al. Lectin binding to cutaneous malignant melanoma: HPA is associated with metastasis formation. Brit J Cancer, v. 84, n. 6, p. 819-23, 2001.

43.WEYERS, W. et al. Spiradenomas in Brooke-Speigler syndrome. Am J Dermatopathol, v. I5, p. I56-60, 1993.

44. YU, L. G. et al. Opposite effects on human colon cancer cell proliferation of two dietary Thomsen-Friedereich antigenbinding lectins. J Cell Physiol, v. I86, n. 2, p. 282-7, 200 I.

45. ZEBDA, N. et al. Expression of PNA-binding sites on specific glycoproteins by human-melanoma cells is associated with a high metastatic potential.J Cell Biochem, v. 54, n. 2, p. I6I 73, 1994.

\section{Mailing address}

Mario Ribeiro de Melo Júnio Laboratório de Imunopatologia Keizo Asami (LIKA), Setor de Patologia, Universidade Federal de Pernambuco (UFPE)

Av. Prof. Morais Rêgo s/n, Campus Universitário CEP 50670-910 - Recife-PE e-mail: mariormj@gmail.com 